\title{
Author Correction: Cryo-EM reveals the structural basis of microtubule depolymerization by kinesin-13s
}

\author{
Matthieu P.M.H. Benoit ${ }^{1}$, Ana B. Asenjo ${ }^{1} \&$ Hernando Sosa ${ }^{1}$
}

Correction to: Nature Communications https://doi.org/10.1038/s41467-018-04044-8, published online 25 April 2018

The previously published version of this Article contained an error in Fig. 5. In panels $\mathrm{f}$ and g, the $\alpha$ and $\beta$ symbols were swapped. The error has been corrected in both the PDF and HTML versions of the Article.

Published online: 11 July 2018

\begin{abstract}
(c) Open Access This article is licensed under a Creative Commons Attribution 4.0 International License, which permits use, sharing, adaptation, distribution and Ceproduction in any medium or format, as long as you give appropriate credit to the original author(s) and the source, provide a link to the Creative Commons license, and indicate if changes were made. The images or other third party material in this article are included in the article's Creative Commons license, unless indicated otherwise in a credit line to the material. If material is not included in the article's Creative Commons license and your intended use is not permitted by statutory regulation or exceeds the permitted use, you will need to obtain permission directly from the copyright holder. To view a copy of this license, visit http://creativecommons.org/licenses/by/4.0/.
\end{abstract}

(C) The Author(s) 2018

\footnotetext{
${ }^{1}$ Department of Physiology and Biophysics, Albert Einstein College of Medicine, Bronx, NY 10461, USA. Correspondence and requests for materials should be addressed to H.S. (email: hernando.sosa@einstein.yu.edu)
} 